\title{
Parental and Peer Influences upon Accounting as a Subject and Accountancy as a Career
}

\author{
Hezlina Mohd Hashim and Abdul Mutalib Embong
}

\begin{abstract}
The study sought to investigate the level of influence between parents and peers of Malaysian school students in selecting their career choice as accountants. The study used a mixed approach of both qualitative and quantitative approaches. The sample comprised of 309 secondary school students studying accounting principle or commerce subject as respondents to this research. The findings revealed that parents, mothers, in particular are more influential in career choice of the secondary school students compared to their peers. The study discovered that parents' educations have no influence over their children's choice of career. The findings from his study will help teachers and educators have a greater sensitivity to, and a better understanding of the impacts parents and peers' influence have on school students' career choice, as accountant is a worthy profession for them to venture into.
\end{abstract}

Index Terms - Career choice, influence, parents, peers.

\section{INTRODUCTION}

Adolescent is the only time where a youth mind is most susceptible to influence, ideas and values which alters the way a person thinks, acts and perceives things. This is a particularly important moment which will affect one's own decision-making processes and career choices. Thus, parents are always assumed to play significant role in shaping and influencing how their school going children make wise career decisions, which inevitably, impact their future career choice. From another perspective, parents are also considered influential which in turn means they also have the ability to influence their child's future. As adolescents are invariably impressionable, their decisions could be very much influenced by their parents, but peers' influence on their choice of career should not be underestimated.

The act of choosing here is referred specially with the notion to pick out or select accounting career as the best or most appropriate of two or more alternatives. An accountancy career as it is referred to in this study, refers to a career in accounting which deals with the production of financial records about a business or an organization.

The career as an accountant is indeed very well recognized and acknowledged before and now. The ACCA President of Malaysia, Dennis Yeates, had declared that Malaysia is expected to require more than 65,000 professional

Manuscript received September 9, 2013; revised November 14, 2013 This work was supported in part by the Universiti Teknologi PETRONAS Short Term Internal Fund,Grant No. 73/2011.The authors would like to thank Universiti Teknologi PETRONAS, Malaysia for their generosity in providing support and research facilities for this research.

Hezlina Mohd Hashim and Abdul Mutalib Embong are with the Department of Management and Humanities, Universiti Teknologi Petronas, Tronoh, Perak, Malaysia (e-mail: hezlina_hashim@petronas.com.my, mutalib_embong@petronas.com.my). accountants by 2020 which is more than twice the number that is available now [1]. The Malaysian Institute of Accountants (MIA) has slightly over 28,000 registered chartered accountants in business and commerce, public practice, public sector and academi as of 2012 [2]. As a fast growing developing country, Malaysia requires to have a great number of accountants to achieve its target by 2020 .

To address this potential demand for accountants, school going children could be persuaded and entice to choose accountancy as their career. The choice made is to know who has impacted the selection of this career line between peers and parents. His or her parents whom are the closest and have paternal and maternal effects on an individual compared to those who are always there and close by an individual and create an environmental effect upon an individual. Hence, the study addresses the effects of two very influential factors: peers versus parents, who would play the most influential role in affecting school students' choice for accountancy as a career. Would it be the parents who have paternal and maternal effects on the children or would it be their peers as they have an environmental effect on the school students' decision.

Many other factors may affect the career selection of the students, however, the minor factors or other factors can be narrowed down to either parents or peers. A thorough understanding of how parents and peers influence the choices of students and who gives more impact to the students together with the psychological understanding of how choices are made and insight of the career line itself allows a good rationalization in determining the more influential party.

One way to determine whether students will major in accounting at university level or not is by looking at them at secondary school level. In general, those who take Accounting Principle (AP) or Commerce subjects at the latter level will have a tendency to join the accounting discipline at tertiary level. In short, it is a sign or the first stage that the students will venture into the accounting field when they further their studies in the university later.

As such, the aim of this paper is to identify the most influential party between parents or peers in choosing accountancy as a career. It is also done to know whether parents' level of education give any influence in students choosing Accounting principle or Commerce subject. The findings seek to assist the educators and educational institutions to have a better understanding of their students on the impact of influences from parents and peers in choosing accountancy as their careers. It is also hoped that the findings may help the institutions and related bodies to develop a better plan that can guide and expose secondary school students to understand the profession clearly. All these initiatives are needed to fill the gap of attracting more 
students to choose accountancy as their careers. As a consequence, it will help to fulfill the desire of the professional accounting bodies in Malaysia to have 65,000 professional accountants by the year 2020. In short, the study poses three research questions as follows:

Research questions

1) Do parents or peers affect the students' decision to choose accountancy as a career?

2) Does parents' level of education influence students in

3) Choosing accounting subjects?

4) Are peers more influential compared to parents in students choosing accounting subjects?

5) Are there any gender differences pertaining to the influence in choosing accounting subjects?

\section{PARENTAL AND PEERS INFLUENCES}

Parental effects on the educational pursuit and attainment of an individual is highly supported and validated in many studies, namely by the study conducted by [3] who found that parental guidance exerts effects on the learning achievement of an adolescent, particularly the socio-economic status of parents. This is further supported with a psychoanalytic theory which relates to childhood experience and memories voluntary and involuntary [4]. These are so often dominated by parents to the choices and mentality of an individual that the chosen occupation is either a duplicate of childhood experience, fulfillment of childhood needs or reify dreams due to familial heritage. Working mothers and homemakers are also great factor that determine the career lines for their daughters and sons in a household [5], [6].

According to [7]-[9] The career of parents is very much related to the careers choices of their children that parents influence, attitudes and values can strongly influence the individual choice of career and is even stronger in socialist culture due to the fact that respect for and obedience to one's parents is often a highly prioritized value.

On the contrary, it is also believed that parental effect on children career choice is not substantial and instead the choices made are very much based on individualism [10].

Subsequently, the effect of peers on career choice can be considered impactful based on the findings of [11]-[13] that showed that students in their teen year are more inclined to be influenced by group norms due to the need to establish a sense of personal identity where it is in-line with the normative expectation of their peers. This is supported by [14] that proves the influence brought by peers does exist alongside that exerted by the parents.

Earlier studies can be related to the findings of [15] and [16] which claim that parental influence is great when it comes to choosing majors. Somehow, parents who are related to a particular field tend to create an environment, which gives their children similar peer effects that relate to the career line they are in. Hence, an early exposure to the career line of the parents relates to the peer influence that is exposed to an individual. Such situations integrate the influence of parents, peers and many more.

Peers are also seen to be another strong factor in influencing students in decision making. The subjective norm is the person's perception that most people who are important to him think he should or should not perform the behavior.
According to the theory, the general subjective norm is determined by the perceived expectations of specific referent individuals or groups, and by the person's motivation to comply with those expectations [17].

\section{Methodology}

A set of questionnaire was developed to collect data on students' perceptions towards the accounting profession. The respondents of the study are form three (aged 15 years oldthird year of lower secondary) and form four students (aged 16 years old- first year of upper secondary), and are taking accounting or commerce classes. Two randomly selected schools from each state which represent the main regions in West Malaysia were used to conduct this study. The states are Penang (northwest region), Selangor (central region), Johor (southern region) and Kelantan (north east region). Two classes of Accounting Principle and Commerce were chosen from each school to conduct the survey, which contributed to the sample size of 360students.

The study was conducted by distributing questionnaires to the students during accounting/commerce class and the students were given approximately 15 minutes to respond to the survey. Two researchers were in the classroom to assist the students with the questions. The objectives of the study were explained clearly to the students and they were assured that their feedbacks would not be used other than for the purposes of this study. The data collected was then analyzed using Statistical Package for Social Science (SPSS) version 11.5 and frequency distribution was used to analyze the data.

\section{RESULTS AND DisCUSSION}

\section{A. Gender Distribution}

The number of female respondents is higher compared to the male. Out of the 309 useable responses, 113 were male and 196 were female (as shown in Table I.)

TABLE I: GENDER DISTRIBUTION

\begin{tabular}{|lll|}
\multicolumn{2}{c}{} & \multicolumn{2}{c}{ TABLE I: GENDER DISTRIBUTION } \\
\hline Gender & Frequency & Percentage \\
\hline Male & 113 & 36.6 \\
Female & 196 & 63.4 \\
\hline
\end{tabular}

\section{A. Parents' Level of Education}

Table II and Table III present the parents' level of education. The analysis of questionnaires suggests that more parents of male students, both fathers $(68.14 \%)$ and mothers $(63.72 \%)$, have lower level of education which are at the primary or secondary school level. Only $31.86 \%$ of the fathers and $36.28 \%$ of the mothers are college or university graduates. The scenario is a bit different for female students where both parents scored about equal distribution between lower level education and college or university graduates. $36.22 \%$ of female students' fathers are educated at primary or secondary school level while $36.73 \%$ of them is college or university graduates. Also, there is a minimal difference in the distribution of the mothers' level of education where $29.08 \%$ is educated at primary or secondary school level while $49.98 \%$ is college or university graduates. Only $2.55 \%$ of the female respondents' mothers are illiterate.

The result seems to indicate that more parents of male 
students are educated at the lower level of education (primary/secondary) compared to female students whose parents' level of education are about equally distributed between lower level (primary/secondary) and higher level (college/university) education. These findings may contribute to the parental influence towards students' career choice as an accountant.

\begin{tabular}{|llll|}
\multicolumn{4}{c}{ TABLE II: FATHERS' LEVEL OF EDUCATION } \\
\hline Gender & Illiterate & $\begin{array}{l}\text { Primary/ } \\
\text { secondary }\end{array}$ & $\begin{array}{l}\text { Higher } \\
\text { education }\end{array}$ \\
\hline Male & 0 & 77 & 36 \\
Female & 0 & 92 & 93 \\
& & & \\
\hline
\end{tabular}

TABLE III: MOTHERS’ LEVEL OF EDUCATION

\begin{tabular}{|llll|}
\hline Gender & Illiterate & $\begin{array}{l}\text { Primary/ } \\
\text { secondary }\end{array}$ & $\begin{array}{l}\text { Higher } \\
\text { education }\end{array}$ \\
\hline Male & 0 & 72 & 41 \\
Female & 5 & 95 & 96 \\
& & & \\
\hline
\end{tabular}

\section{B. Parents' Education versus Influence}

Parents' education background was also a part of this study. It was done to see if parents' background of education affects the students' choice of influence between parents or peers. For fathers' level of education in Table IV, there are not many differences between primary/secondary and higher education. $12.30 \%$ of students whose fathers' level of education is primary/secondary chose parents as their main influence while $10.36 \%$ students whose fathers' level of education is higher education chose the same answer. $10.36 \%$ of students with primary/secondary education fathers chose peers as their main influence while $9.39 \%$ students from higher educated fathers chose peers.

In term of mothers' level of education (see Table V), $12.62 \%$ of students whose mothers' level of education is primary/secondary chose parents as their major influence in selecting AP/commerce subject whereas $7.77 \%$ of higher educated mothers chose the same answer. 5.83\% of students with primary/secondary education mothers chose peers as their main influence in selecting AP/Commerce subject while $9.71 \%$ from higher educated mothers chose their friends under the same subject.

TABLE IV: FATHERS' LEVEL OF EDUCATION VERSUS INFLUENCE TO TAKE ACCOUNTING PRINCIPLE/COMMERCE SUBJECT (IN \%)

\begin{tabular}{|lll|}
\hline Level of education & Parents & Peers \\
\hline Primary / secondary & 12.30 & 10.36 \\
Higher education & 10.36 & 9.39 \\
\hline
\end{tabular}

TABLE V: MOTHERS' LEVEL OF EDUCATION VERSUS INFLUENCE

\begin{tabular}{|lll|}
\hline Level of education & Parents & Peers \\
\hline Primary / secondary & 12.62 & 5.83 \\
Higher education & 7.77 & 9.71 \\
\hline
\end{tabular}

The findings suggest that fathers' level of education does not give much impact to students' influence of subject choice, accounting subject in particularly. On the other hand, students' mothers with primary/secondary level of education has given more influence in advising students to take AP or commerce subject compared to their peers. This may be due to mothers have stronger influence towards children which is in line with research done by [18] which discovered that mothers are not only influential parents to daughters but also to sons as well.

The respondents were then asked whether they were being forced by their parents to undertake the subject of AP or commerce or not (as shown in Table VI). Out of 113 students, no male students stated that they were forced by their parents to enroll in the said subject while $15 \%$ of them were not sure whether they were being forced by their parents or not. On the other hand, $9.18 \%$ of female students perceived that they were being forced by their parents to undertake the subject while $6.12 \%$ was unsure if they were being forced by their parents or not. Overall, $84.79 \%$ did not agree that they were forced by their parents to take the subject of Accounting Principle (AP) or Commerce compared to only 5.83\% who agreed that they were forced by their parents to take the subject.

The result suggests that majority of the students were not being forced by their parents in choosing and selecting the subject of AP or Commerce. This is considered normal in modern society where career choice is viewed as a means of self- actualization and fundamentally as an individual choice [19].

TABLE VI: PARENTS FORCED STUDENTS TO UNDERTAKE THE SUBJECT OF ACCOUNTING PRINCIPLE/COMMERCE

\begin{tabular}{|llllll|}
\hline Gender & $\begin{array}{l}\text { Strongly } \\
\text { do not } \\
\text { agree }\end{array}$ & $\begin{array}{l}\text { Do not } \\
\text { agree }\end{array}$ & $\begin{array}{l}\text { Not } \\
\text { sure }\end{array}$ & Agree & $\begin{array}{l}\text { Strongly } \\
\text { agree }\end{array}$ \\
\hline Male & 65 & 31 & 17 & 0 & 0 \\
Female & 147 & 19 & 12 & 7 & 11 \\
\hline
\end{tabular}

One question was asked if their parents would want the students to be accountants (refer to Table VII). $20.35 \%$ of male students agreed that their parent want them to be accountants while $63.72 \%$ was not sure about it. Only $15.93 \%$ said that their parents did not want them to be accountants.

For female students, $50 \%$ agreed that their parents wanted them to be accountants while $29.1 \%$ was not sure and $20.92 \%$ did not agree that their parents want them to become accountants.

Overall, only $19.09 \%$ of both male and female students disagreed that their parents want them to be accountants while $39.16 \%$ agreed with the statement. The overall result suggests that more parents of the students want their children to be accountants. However, higher percentage of female students' parents would like them to proceed with the career compared to male students with lower percentage of having the same desire for their sons.

The respondents were then asked on who advised them to take AP/commerce subject (as shown in Table VIII). For male students, $16.8 \%$ chose parents as their advisor, $17.7 \%$ chose peers while the rest chose other people such as counselors, teachers and other sources as their advisor. In contrast, almost half of the female respondents (48.9\%) chose parents as the responsible person to advise them on taking AP/commerce subject, $23.3 \%$ chose peers while the rest 
chose other sources.

TABLE VII: PARENTS WOULD LiKE THE STUDENTS TO BE ACCOUNTANTS

\begin{tabular}{|llllll|}
\hline Gender & $\begin{array}{l}\text { Strongly } \\
\text { do not } \\
\text { agree }\end{array}$ & $\begin{array}{l}\text { Do not } \\
\text { agree }\end{array}$ & $\begin{array}{l}\text { Not } \\
\text { sure }\end{array}$ & Agree & $\begin{array}{l}\text { Strongly } \\
\text { agree }\end{array}$ \\
\hline Male & 0 & 18 & 72 & 18 & 5 \\
Female & 7 & 34 & 57 & 46 & 52 \\
\hline
\end{tabular}

It can be concluded that majority of the male students seek advice from the other sources like teachers and counselors while female students prefer to get advice from their parents more than peers and other sources.

TABLE VIII: PERSON WHO AdVISED THE STUDENTS ON TAKING ACCOUNTING PRINCIPLE/COMMERCE SUBJECT

\begin{tabular}{|llll|}
\hline Gender & Parents & Peers & Others \\
\hline Male & 19 & 20 & 74 \\
Female & 94 & 45 & 53 \\
\hline
\end{tabular}

\section{Peers Influence}

In order to see if peers influence exists among the students in choosing career as an accountant, two questions were asked as in Table IX and X. From Table IX, $18.59 \%$ of male students did not agree that they took the subject of AP/Commerce because of their friends. $68.14 \%$ agreed on the matter while $13.28 \%$ was not sure of the answer. For female students, only $7.14 \%$ did not agree that they took the subject because of their friends. Meanwhile, $82.65 \%$ agreed on the peers influence on their decision making and other $10.2 \%$ were not sure. Overall, only $11.32 \%$ for both male and female students did not agree that they took the subject because of their friends while $77.35 \%$ agreed with it.

The findings suggest that more students agreed that they took the subject of AP/Commerce because of their friends. However, female students scored higher percentage compared to male students. It indicates that peers have influence in the students choosing accounting subjects. Female students also can be seen more influenced by their peers compared to the male students.

TABLE IX: FRIENDS ALSO TOOK THE SUBJECT OF ACCOUNTING PRINCIPLE/COMMERCE

\begin{tabular}{|llllll|}
\hline Gender & $\begin{array}{l}\text { Strongly } \\
\text { do not } \\
\text { agree }\end{array}$ & $\begin{array}{l}\text { Do not } \\
\text { agree }\end{array}$ & Not sure & Agree & $\begin{array}{l}\text { Strongly } \\
\text { agree }\end{array}$ \\
\hline Male & 13 & 8 & 15 & 39 & 38 \\
Female & 0 & 14 & 20 & 117 & 45 \\
\hline
\end{tabular}

A question was posed on peers' views on the career choice made by the students (Table X). When asked if peers would think the students have made a good career decision if they became an accountant, $24.78 \%$ of male students did not agree with that statement, $27.4 \%$ agreed, meanwhile $47.79 \%$ were not sure of what their friends think about it. For female students, $3.57 \%$ did not agree with it while $60.71 \%$ thought their friends would agree with them on their career decision.

Overall, only $11.33 \%$ of both female and male students disagreed with the statement that peers would think the students have made a good career decision if they become accountants while $48.54 \%$ have opposite opinions on the same matter.
The result suggests that male students have a mixed view over this matter while more female students agreed that they consider their friends' views in their career decision of being accountants. Overall result also shows that in general, students did consider their friends' views towards their career choices as accountants.

The findings support the previous studies by [20], [21], [24] that discovered that close friends have significant influence on students' major choice when studying accounting. Peers or friends [29]-[31] may provide information, opinions, verbal encouragement, and support regarding the selection of their major subjects. This is however contradicted with the findings of [23] where peers had very little influence on their decision.

Hence, it is concluded that students' friends or peers did influence their choice of a career as accountants. However, parents are of greater influence if compared to peers in terms of making career decisions. This is supported by the findings of [32].

TABLE X: My PEers WOULd THINK I HAVE MADE A GOOD CAREER

\begin{tabular}{|llllll|}
\multicolumn{7}{c|}{ DECISION IF I BECOME AN ACCOUNTANT } \\
Gender & $\begin{array}{l}\text { Strongly } \\
\text { do not } \\
\text { agree }\end{array}$ & $\begin{array}{l}\text { Do not } \\
\text { agree }\end{array}$ & $\begin{array}{l}\text { Not } \\
\text { sure }\end{array}$ & Agree & $\begin{array}{l}\text { Strongly } \\
\text { agree }\end{array}$ \\
\hline Male & 0 & 28 & 54 & 31 & 0 \\
Female & 7 & 0 & 70 & 63 & 56 \\
\hline
\end{tabular}

\section{CONCLUSION}

It is apparent from this review of the literature that the influences of parents, and peers, help the students to make decision in choosing accounting as a major subject. Parents are more influential in students' career choices as compared to peers. As students interact with their peers, their advice give less impact and important as compared to parents.

In this study, a more positive influence can be observed from the parents compared to peers. In addition, there are gender differences in some areas of influence in choosing the accounting subject.

The finding of this study suggests that there is a greater influence from the family towards female students compared to male students on the students to be accountants. It supports the previous studies done by [20]-[24] that parents have a great influence in students' decision. The findings also are in line with the findings of [25]-[29] who reported that parental influence was relatively stronger compared to peers influence.

Thus, it is concluded that parents were the primary individuals who influenced students' choice of a career although mothers were more influential compared to fathers. In one study [29], this influence has been so strong as to override the influence of teachers, faculty, and career counselors, who would likely know more about the career field but were not as well-known and/or trusted as the student's parents for this type of decision.

It is also hoped that the findings from this study may help teachers, schools and other related bodies to develop a better plan that can guide and expose secondary school students to understand accounting as a profession clearly. As a consequence, it may help Malaysia to fulfill her desire to 
achieve the targeted number of 65,000 professional accountants by the year 2020 .

The major limitation of this study is the inability to generalize from the findings which may not be able to represent the whole picture of what is happening in this country. Before recommendations are made to improve the exposure of accountancy as a great career to students, more researches need to be conducted. The sample size is relatively small which comes from few randomly selected schools in Malaysia.

Future research could extend the sample to all states in Malaysia including Sabah and Sarawak (East Malaysia). The study can also be replicated to other countries as well as to university students. Another likely extension of this study would be to investigate to the numbers of students proceeding with an accounting as a major in universities.

\section{REFERENCES}

[1] Bernama. (June 5, 2012). MIA supports call for more chartered accountants. The Star. [Online]. Available: http://www.thestar.com.my/story.aspx?file $=\% 2 \mathrm{~F} 2012 \% 2 \mathrm{~F} 6 \% 2 \mathrm{~F} 5 \% 2$ Fbusiness\%2F11416477\&sec=business

[2] R. Ramly. (Nov 30, 2006). ACCA, guardian of the accounting profession. [Online]. Available: http://bernama.com.my/bernama/v3/bm/printable.php?id=233369, 2006.

[3] H. I. Alika and E. O. Egbochuku, "Vocational interest, counseling, socio-economic status and age as correlates of the re-entry of girls into school," Edo Journal of Counseling, vol. 2, no. 1, pp. 9, May 2009.

[4] A. M. Pines and O. Y. Yanai, "Unconscious determinants of career choice and burnout: Theoretical model and counseling strategy," Journal of Employment Counseling, vol. 38, no. 4, pp. 170-184, 2001.

[5] L. B. Otto, "Youth perspectives on parental career influence," Journal of Career Development, vol. 27, pp. 111-17, 2000.

[6] S. Knowles, "Effects of the components of parent involvement on children's educational and occupational aspirations," Unpublished doctoral dissertation, Alfred University, Alfred, New York, 1998.

[7] D. Brown, "The role of work and cultural values in occupational choice, satisfaction, and success: A theoretical statement." Journal of Counseling and Development, vol. 80, pp. 48-56, Winter 2002.

[8] D. W. Sue and D. Sue, Counseling the Culturally Different, 2nd ed., New York: Wiley, 1990.

[9] D. T. Yagi and M. Y. Oh, "Unemployment and family dynamics in meeting the needs of the Chinese elderly in the United States," Gerontologist, vol. 25, pp. 472-476, 1995.

[10] M. O. Oyebode, "The influence of parental education on the level of vocational aspiration of class three and four students of Lagos area," presented at the Nigerian Psychological Conference, Lagos, Nigeria, 1980.

[11] G. M. Breakwell and S. Beardsell, "Gender, parental and peer influences upon science attitudes and activities," Public Understanding of Science, vol. 1, no. 2, pp. 183-197, 1992.

[12] E. L. Talton and R. D. Simpson, "Relationships of attitude toward classroom environment with attitude toward and achievement in science among tenth grade biology students," Journal of Research in Science Teaching, vol. 24, no. 6, pp. 507-525, 1987.

[13] J. O. Head, The Personal Response to Science, Cambridge: Cambridge University Press, 1985.

[14] C. O. Eckerman and S. W. Didow, "Lessons drawn from observing young peers together," Acta Paediatrica Scandinavica, vol. 77, pp. $55-70,1988$

[15] L. N. Calkins and A. Welki, "Factors that influence choice of major: Why some students never consider economics," International Journal of Social Economics, vol. 33, no. 8, pp. 547-564, 2006.

[16] J. Farley and O. Staniec, "The effects of race, sex, and expected returns on the choice of college major," Eastern Economic Journal, vol. 30, no. 4, pp. 549-563, 2004

[17] M. Fishbein and I. Ajzen, "Belief, attitude, intention, and behavior: An introduction to theory and research," Addison-Wesley, Reading, MA, 1975.

[18] M. A. Boatwright, M. Ching, and A. Parr, "Factors that influence students' decisions to attend college," Journal of Instructional Psychology, vol. 19, no. 2, pp. 79-8, 1992.
[19] M. Tang, N. A. Fouad, and P. L. Smith, "Asian-Americans' career choices: A path model to examine factors influencing their career choices," Journal of Vocational Behavior, vol. 54, no. 1, pp. 142-57, 1999.

[20] J. Cohen and D. Hanno, "An analysis of underlying constructs affecting the choice of accounting as a major," Issues in Accounting Education, vol. 8, no. 2, pp. 219-38, 1993

[21] C. Allen, "Business students' perception of the image of accounting," Managerial Auditing Journal, vol. 19, no. 2, pp. 235-58, 2004.

[22] S. Sugahara and G. Boland, "Perceptions of the Certified Public Accountants by accounting and non-accounting tertiary students in Japan," Asian Review of Accounting, vol. 14 no. 1, pp. 149-167, 2005.

[23] M. Byrne and B. Flood, "A study of accounting students' motives, expectations and preparedness for higher education," Journal of Further and Higher Education, vol. 29, no. 2, pp. 111-124, 2005

[24] L. M. Tan and F. Laswad, "Students' beliefs, attitudes and intentions to major in accounting," Accounting Education: An International Journal, vol. 15 , no. 2 , pp. $167-187,2006$

[25] T. A. Fisher and M. B. Griggs, "Factors that influence the career development of African American and Latino youth," Journal of Vocational Education Research, vol. 20, no. 2, pp. 57-74, 1995

[26] M. L. Houser and E. P. Yoder, "Factors related to the educational and career choices of talented youth," in Proc. 19th National Agricultural Education Research Meeting, St. Louis, MO, 1992, pp. 400-407.

[27] B. C. Inman, A. Wenzler, and P. D. Wickert, "Square pegs in round holes: Are accounting students well-suited to today's accounting profession?" Issues in Accounting Education. vol. 4, no. 1, pp. 29-47, Spring 1989.

[28] R. Silverstone and A. Williams, "Recruitment, training, employment and careers of women Chartered Accountants in England and Wales," Accounting and Business Research, vol. 9, no. 33, pp. 105-121, 1979.

[29] S. Mauldin, J. L. Crain, and P. H. Mounce, "The accounting principles instructor's influence on student's decision to major in accounting," Journal of Education for Business, vol. 75, no. 3, pp. 142-148, 2000.

[30] K. M. Bartol, "Expectancy theory as a predictor of female occupational choice and attitude toward business," Academy of Management Journal, vol. 19, pp. 669-675, 1976.

[31] L. N. Calkins and A. Welki, "Factors that influence choice of major: Why some students never consider economics," International Journal of Social Economics, vol. 33, no. 8, pp. 547-564, 2006.

[32] D. W. Roach, R. E. Gaughey, and J. P. Downey, "Selecting a business major within the college of business," Administrative Issues Journal: Education, Practice and Research, vol. 2, no. 1, pp. 5, April 2012.

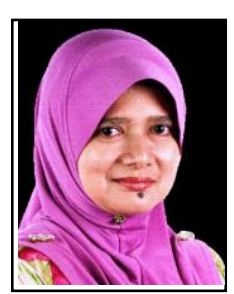

Hezlina Mohd Hashim was born in Kedah, Malaysia in July 1972. She has obtained a Bachelor degree in Accounting from Universiti Utara Malaysia, Kedah, Malaysia in 1996 and Master in Business Administration from Universiti Kebangsaan Malaysia, Selangor, Malaysia in 2004. She is a lecturer in the Department of Management \& Humanities at Universiti Teknologi PETRONAS, Malaysia. In this role, apart from teaching, she is responsible to secure research grants, conduct research, publish academic papers in journals and conference proceedings, supervise students and involve in university and committee activities. She has over 15 years of working experience in the industry ( 4 years) and education (11 years) fields. At her current workplace, she taught accounting subjects like Business Accounting, Financial Accounting and Management Accounting. Her major research interests are on accounting education and management accounting. She has authored and co-authored a number of papers. Her most recent publication is titled "Perceptions on accounting career: A study among the secondary school students in a regional Kelantan state."

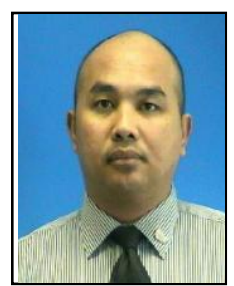

Abdul Mutalib Embong was born in Kuala Lumpur, Malaysia in March 1970. He holds a M. Ed. TESL from Universiti Pendidikan Sultan Idris (UPSI) Malaysia and a Bachelor's Degree in Mass Communication from Universiti Teknologi MARA, Malaysia. He is a Social Science and Humanities PhD candidate and a lecturer in Universiti Teknologi PETRONAS. He has more than 18years experience in teaching. His research interests include education and technology, and discourse analysis. At present, he lectures English at foundation level in UTP. He is currently conducting an epistemological research on British Discourse and has authored many papers for journals and conference proceedings. His recent publication is titled "E-books as textbooks in the classroom". 